\title{
DEVELOPMENT OF COASTAL PROTECTION MEASURES FOR SMALL ISLANDS IN THE WADDEN SEA USING A RISK-BASED APPROACH
}

\author{
Theide Wöffler ${ }^{1}$, Holger Schüttrumpf ${ }^{2}$, Arne Arns $^{3}$, Hilmar von Eynatten ${ }^{4}$, Roger Häußling ${ }^{5}$, Jürgen Jensen ${ }^{6}$ and
} Malte Schindler

The Halligen in the Northfrisian part of the UNESCO - World Natural Heritage Wadden Sea are exposed to extreme storm surges due to climate change and sea level rise. Existing coastal protection measures in this area do not consider the future sea state and are mainly based on tradition and expert knowledge. The presented work is part of the project ZukunftHallig (supported by the German Coastal Engineering Research Council) and has the main objective to design and evaluate new coastal protection techniques and management strategies for the Halligen. With numerical simulations hydrological parameters are investigated. Furthermore sensitivity analyses expose possible variations in future storm surges and illustrate the difference in significant wave heights for varying wind climates. This risk based approach of the project is a suitable way to ensure life for future generations on these islands under sustainable ecological und economic conditions.

\section{INTRODUCTION}

The Northfrisian Halligen are small undiked marsh islands and were formed during the Middle Ages by great storm surges that destroyed vast marshlands (Ehlers 1988). They are located in the German part of the UNESCO - World Natural Heritage Wadden Sea (Figure 1).

As they do not have dikes and rise only a few meters above the middle high tide, the ten Halligen are inundated several times during the storm surge season. As a protection against these high waters the citizens have built their houses on dwelling mounds that lay up to six meter above sea level. Nevertheless, these protection measures are limited and do not consider possible variations in the future sea state due to climate change.

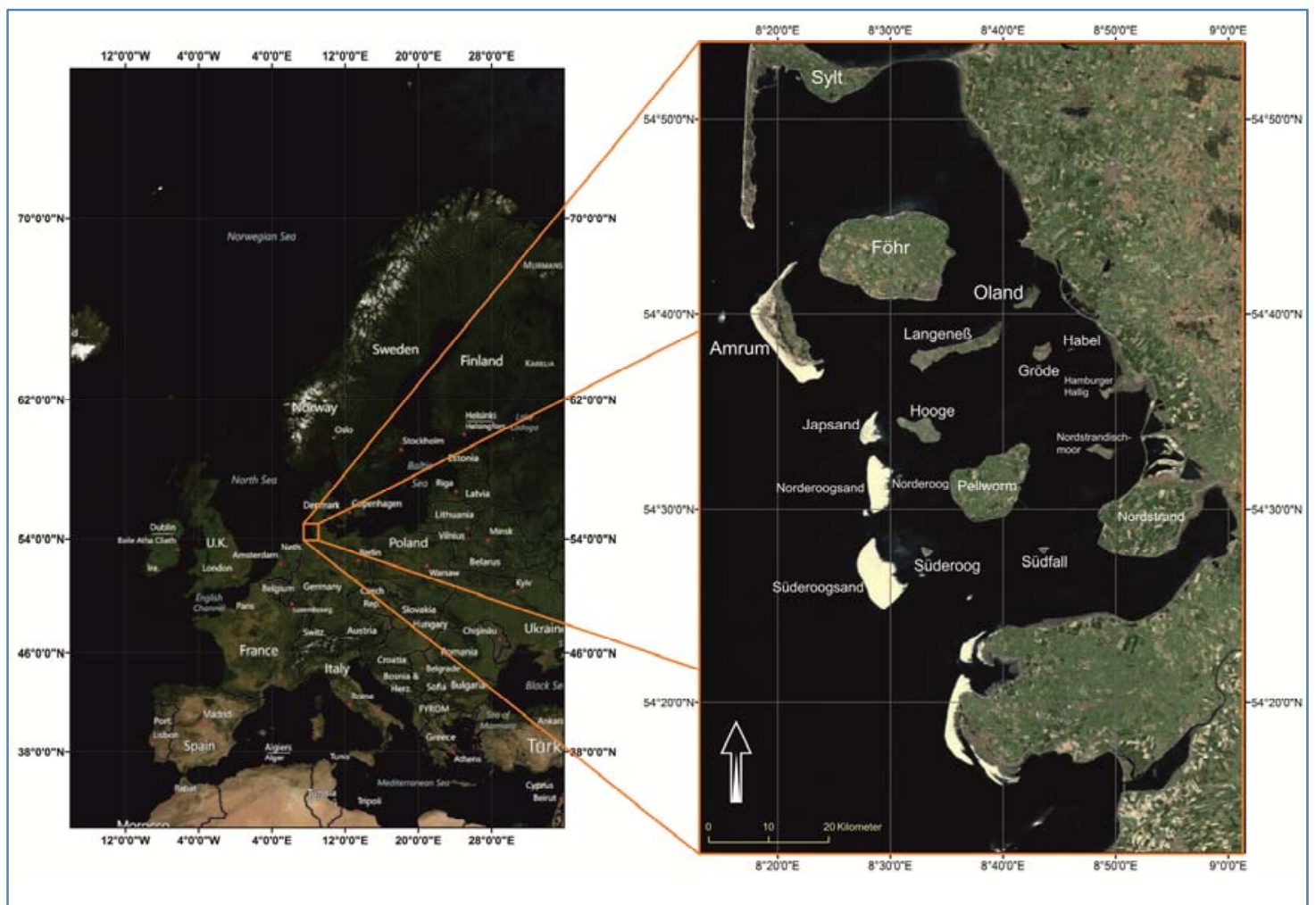

Figure 1. Location of the Northfrisian islands and Halligen

\footnotetext{
${ }^{1}$ Institute of Hydraulic Engineering and Water Resources Management, RWTH Aachen University, Germany

${ }^{2}$ Institute of Hydraulic Engineering and Water Resources Management, RWTH Aachen University, Germany

${ }^{3}$ Research Institute for Water and Environment, University of Siegen, Germany

${ }^{4}$ Geoscience Center, University of Göttingen, Germany

${ }^{5}$ Sociology of Technology and organizations, Institute of Sociology at RWTH Aachen University, Germany

${ }^{6}$ Research Institute for Water and Environment, University of Siegen, Germany

${ }^{7}$ Geoscience Center, University of Göttingen, Germany
} 
In Table 1 the ten Northfrisian Halligen and data on their area, coastline and inhabitants are listed.

\begin{tabular}{|l|ccc|}
\hline \multicolumn{4}{|c|}{ Table 1. Data on the ten Northfrisian Halligen } \\
\hline & $\begin{array}{c}\text { Area } \\
\left(\mathrm{km}^{2}\right)\end{array}$ & $\begin{array}{c}\text { Coastline } \\
(\mathrm{km})\end{array}$ & Inhabitants \\
\hline Langeneß & 9.241 & 21.126 & 123 \\
Hooge & 5.460 & 11.066 & 83 \\
Oland & 0.955 & 4.930 & 29 \\
Nordstrandischmoor & 1.630 & 6.759 & 18 \\
Gröde & 1.965 & 7.544 & 8 \\
Hamburger Hallig & 0.493 & 3.092 & 0 \\
Süderhoog & 0.577 & 3.074 & 2 \\
Südfall & 0.407 & 2.963 & 0 \\
Habel & 0.063 & 1.511 & 0 \\
Norderoog & 0.079 & 1.359 & 0 \\
\hline total & 20.870 & 63.424 & 263 \\
\hline
\end{tabular}

The Halligen also profit from these inundations as the accumulation of sediments elevates their flat surfaces. Because of their low elevation the ten Northfrisian Halligen will be particularly affected by climate change and accelerated sea level rise. The project ZukunftHallig has the objective to develop new coastal protection measures and sustainable management strategies.

\section{METHODS}

To perform the risk based hazard analyses it is important to have knowledge about the input parameters that influence the storm surge risk. The risk $R$ is defined as the product of the probability $P_{\mathrm{f}}$ of an event and the consequences $E(D)$ that result from this event (Merz 2006):

$$
R=P_{f} \cdot E(D)
$$

Figure 2 displays the influence of climate change on storm surge risk and the main factors that affect the calculated risk.

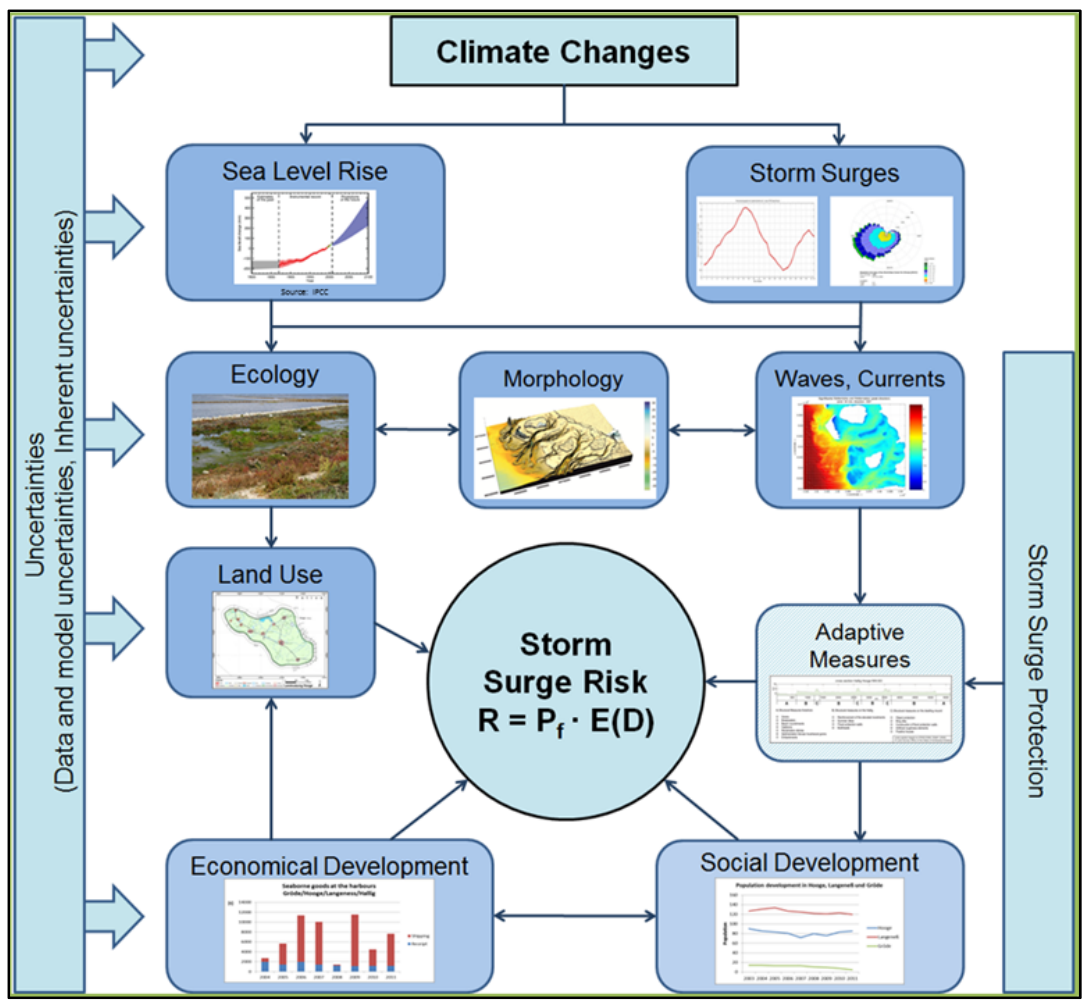

Figure 2. Evaluation of the storm surge risk 
As climate change directly influences the rise of the sea level and the estimated storm surges, it also affects the wave climate and the extreme water levels in the Wadden Sea. The regional rise of the sea level and extreme sea levels are investigated by the Research Institute for Water and Environment (fwu), University of Siegen, within this project (Arns et al. 2012). These changing hydrological boundary conditions also interact with the morphology, vegetation and the ecology.

Therefore, the influence of climate change on the morphology of the Halligen and the sedimentation processes are investigated by the Geoscience Center of the University of Göttingen and will be considered in the risk analysis.

The existing coastal protection measures like revetments and dwelling mounds on the Halligen are based on tradition and do not consider future developments. With the help of risk based hazard analyses and different numerical tools (Delft3D, ProMaIDes) the future of these small islands as well as adaptive measures are investigated in the framework of the interdisciplinary research project ZukunftHallig. Thus, storm surge protection measures and land use management strategies have to be adapted to climate change. The possible actions, while considering the above mentioned processes, include technical flood protection as well as flood precaution measures.

Furthermore, factors like social and economic development influence the storm surge risk in an important manner. For this reason the Institute of Sociology of the RWTH Aachen University is part of the interdisciplinary project ZukunftHallig. Nevertheless, there are some inherent uncertainties in the input data and the numerical models that affect the storm surge risk analysis. These uncertainties will also be considered within the research.

\section{INPUT DATA}

\section{Morphology}

The morphology of the Northfrisian Wadden Sea is a highly dynamic system with many different components that interact and influence each other.

As shown in Figure 3 the bathymetry is characterized by tidal ebb deltas and outer sands towards the open sea. Tidal inlets flush and drain the area of the tidal flats which run dry during low tide and are flooded during high tide. This system, with its shoal bathymetry, has also an important function in the coastal protection of Schleswig-Holstein as the components act as a first defence line for the dikes on the mainland (Ehlers 1988).

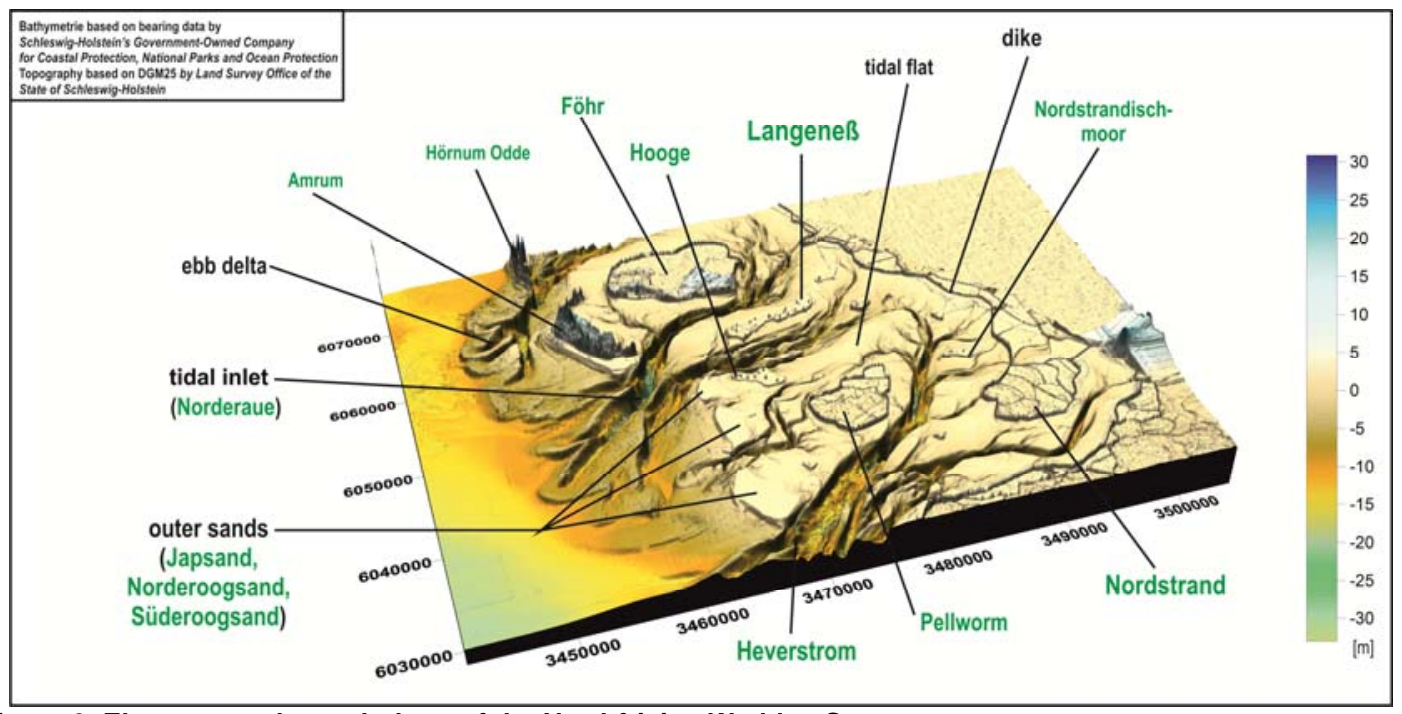

Figure 3. Elements and morphology of the Northfrisian Wadden Sea

The digital elevation model of the investigated area is based on the airborne laser scan data set DGM1 by the Land Survey Office of the State of Schleswig-Holstein. The digital bathymetry model is based on bearing data by Schleswig-Holstein's Government-Owned Company for Coastal Protection, National Parks and Ocean Protection.

Wind

As another input parameter for the risk-based hazard analysis, measured wind data from the Wind station at Hallig Hooge is analysed. The period of time is from the year 1969 to 2011 and the temporal resolution is one hour. The highest measured wind speeds at Hallig Hooge have been the two storms 
Anatol (3th December 1999) and Capella (3th January 1976) with wind speeds up to 28.6 meters per second.

To simulate the sea state for future conditions wind fields of the Climate Local Model (CLM) based on the emission scenarios of the IPCC A1B and B1 are statistically analysed and used as respective boundary conditions. The IPCC-Scenario A1B is grounded on big economic growth and balanced use of all energy sources. The global average surface warming at the end of the $21^{\text {st }}$ century of this scenario amounts $2.8^{\circ} \mathrm{C}$ with a likely range from $1.7{ }^{\circ} \mathrm{C}$ to $4.4{ }^{\circ} \mathrm{C}$. IPCC-Scenario $\mathrm{B} 1$ is grounded on global sustainability and the use of resources-efficient technologies. In contrast to emission scenario A1B the projected global temperature change amounts only $1.8^{\circ} \mathrm{C}$ with a likely range of $1.1-2.9^{\circ} \mathrm{C}$ (Pachauri \& Reisinger 2007).

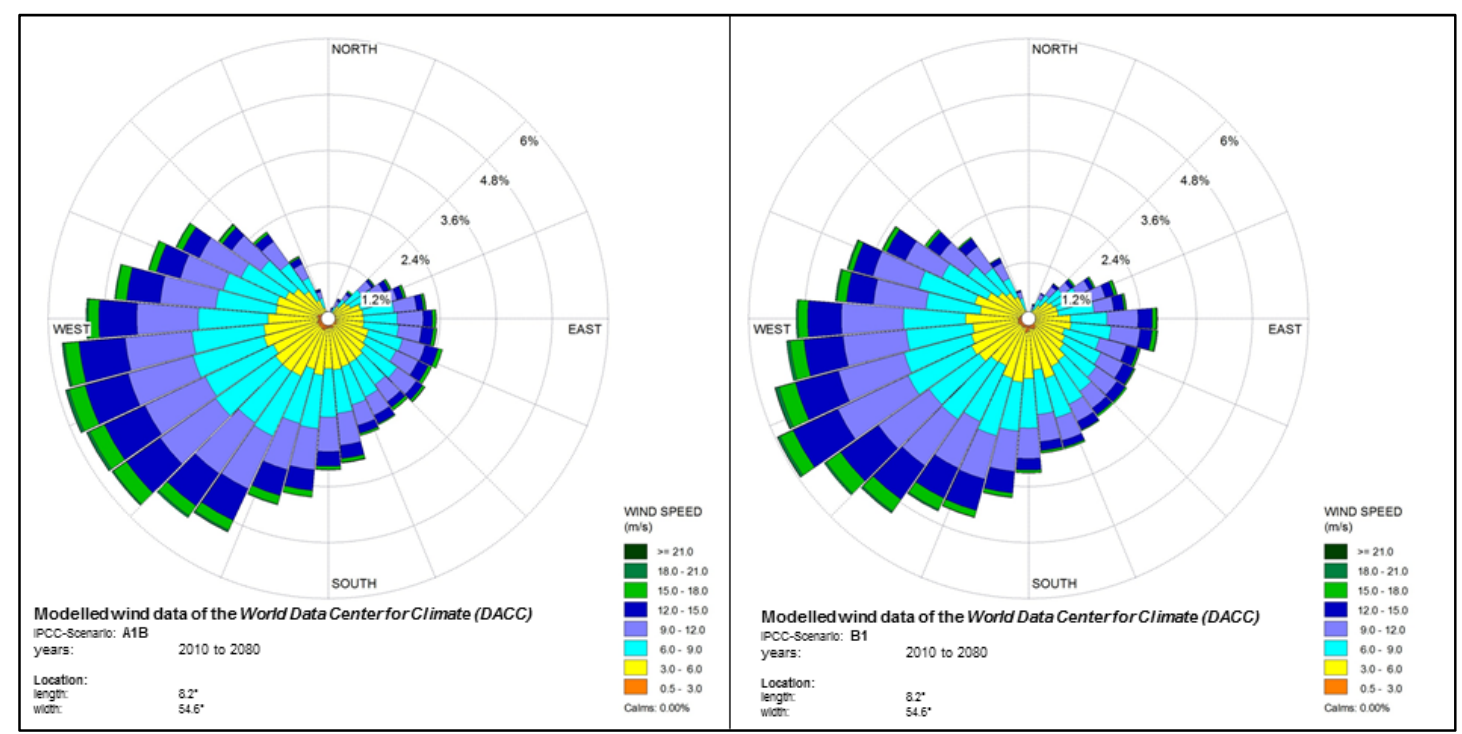

Figure 4. Modelled wind data of the World Data Center for Climate (WDCC) for the location length: $8.2^{\circ}$ and width $54.6^{\circ}$ based on IPCC-Scenario A1B (left) and IPCC-Scenario B1 (right)

Figure 4 shows the frequency and speed of the different wind directions. The values are daily means for the years 2010 to 2080 and modelled for the location with the coordinates $8.2^{\circ}$ (length) and $54.6^{\circ}$ (width).

In IPCC-Scenario A1B the main wind direction is $245-255^{\circ}$. This direction occurs in $5.81 \%$ of this modelled scenario. Wind speeds over $20 \mathrm{~m} / \mathrm{s}$ occur in $0.17 \%$ of the model data for this location. The top wind speed for scenario A1B is $23.68 \mathrm{~m} / \mathrm{s}$ from the direction $210^{\circ}$. In IPCC Scenario B1 the main wind direction is $235-245^{\circ}$. Wind speeds over $20 \mathrm{~m} / \mathrm{s}$ have a relative frequency of $0.15 \%$. The top wind speed for scenario B1 is from the direction

\section{Waves}

Besides currents, tides and water-levels, waves are the most important factor for the measuring of coastal protection elements. Factors like wave run up and wave overtopping can be calculated from the knowledge of the wave parameters significant wave height and wave period (Eurotop 2007).

Schleswig-Holstein's Government-Owned Company for Coastal Protection, National Parks and Ocean Protection (LKN-SH) operates four wave buoys of the type Directional Waverider Mark II by Datawell at the following locations in the area of investigation (Table 2).

\begin{tabular}{|c|cc|c|}
\hline \multicolumn{3}{|c|}{ Table 2. Positions of the wave buoys operated by LKN-SH } \\
(Directional Waverider Mark II by Datawell) \\
\hline & \multicolumn{2}{|c|}{ Position } & \\
Buoy & Easting & Northing & Period \\
\hline Rütergat & 3448920 & 6041958 & since 07/2001 \\
Süderaue & 3471770 & 6052071 & since 03/2007 \\
Norderhever & 3483039 & 6042013 & since 11/1994 \\
Süderhever & 3460293 & 6018593 & since 01/1995 \\
\hline
\end{tabular}


Figure 5 illustrates a comparison of the values of the significant wave heights at the wave buoys Süderhever and Norderhever for November of the year 2007. The wave heights at the location of the buoy Norderhever are notably smaller because of the more sheltered location in the back of the Wadden Sea and the protective effect of the high shoals. Wave heights of storm surge Tilo can be found in the range of hour 192 and 230. The maximum significant wave height at wave buoy Süderhever reached a value of about $4.2 \mathrm{~m}$ whereas the maximum at wave buoy Norderhever was about $1.2 \mathrm{~m}$.

As these wave buoy measurements can only submit punctual wave data, numerical simulation have to be performed to evaluate future scenarios.

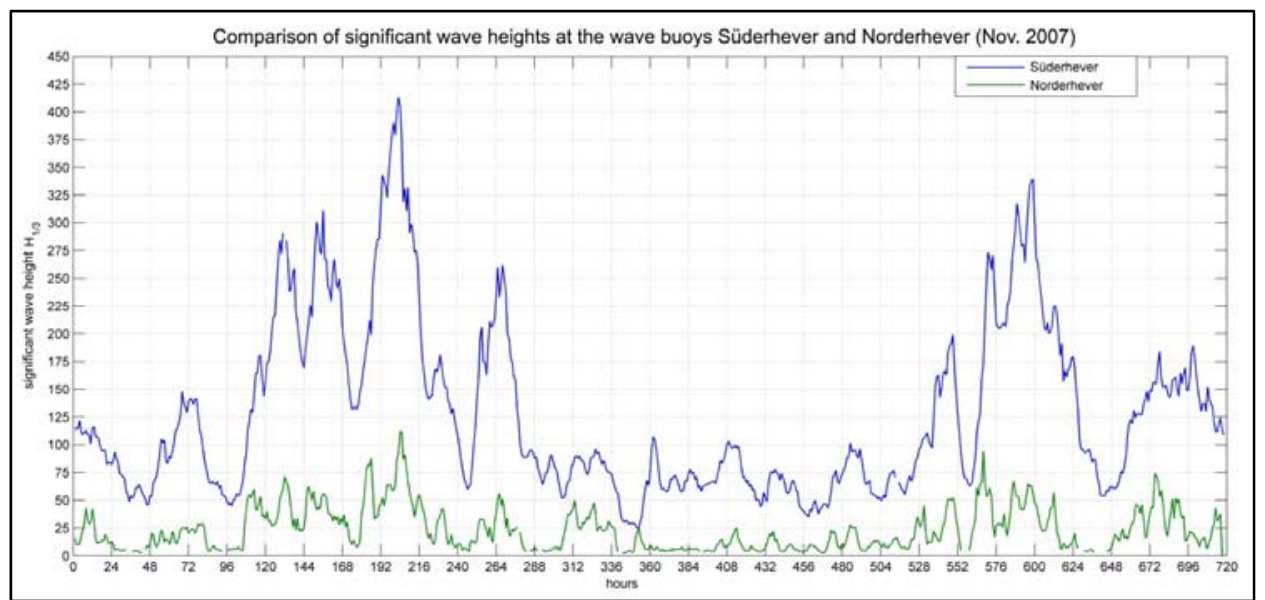

Figure 5. Comparison of significant wave heights at the wave buoys Süderhever and Norderhever for November 2007

\section{Land Use}

Due to the frequent inundations and the sedimented salt a cultivation of crop is not possible on the Halligen. The low summer dikes that were built at several Halligen allow at least the keeping of cattle during the summer months. Because of that most of the island's small surfaces is used as green land. The few houses of the inhabitants are built on dwelling mounds (Figure 6).

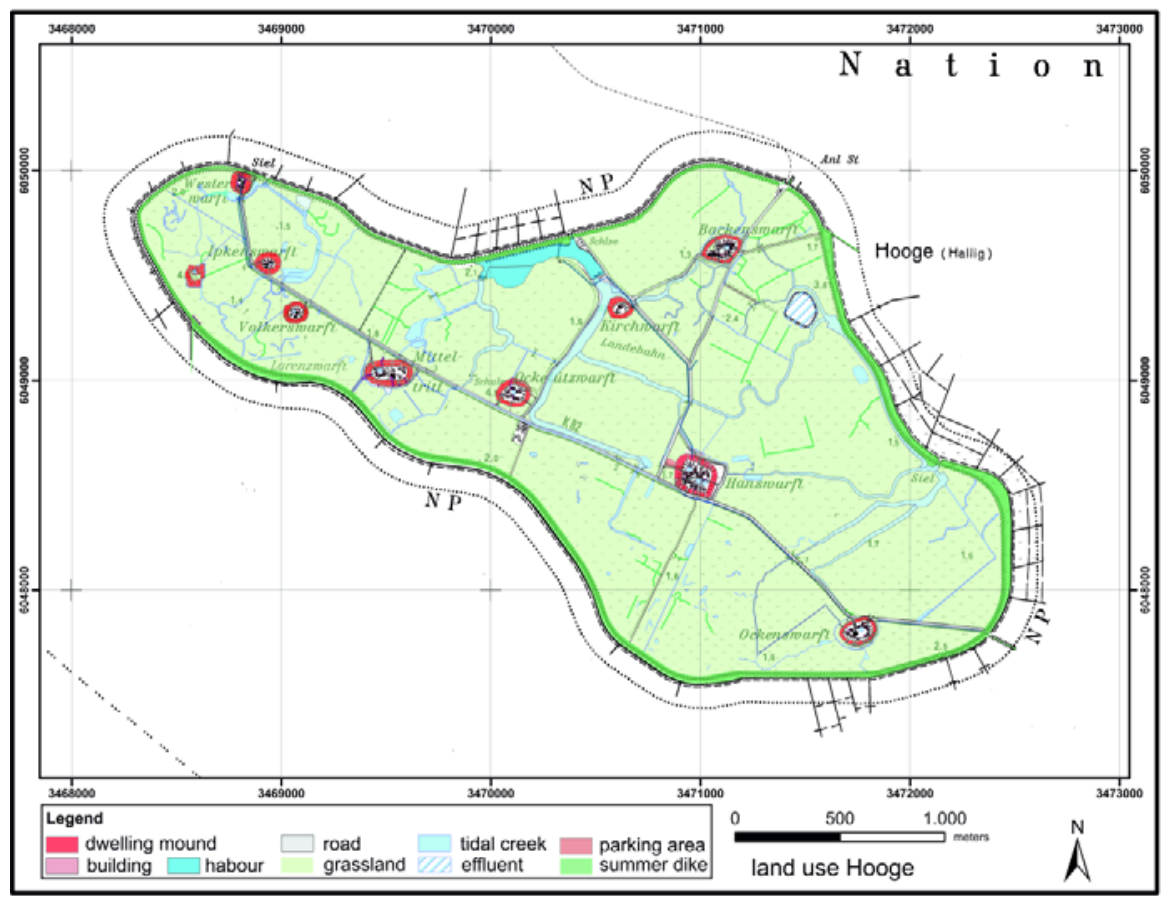

Figure 6. Land use of Hallig Hooge based on ALK-Data by the Land Survey Office of the State of SchleswigHolstein 
The land use on Hallig Hooge is dominated by agricultural greenland and the ten dwelling mounds as the areas of settlement make out only a few percent. Altogether there are 78 dwellings on Hallig Hooge with a living area of about $7500 \mathrm{~m}^{2}$.

\section{NUMERICAL SIMULATIONS}

\section{North Sea Model}

In a first step the software package Delft3D by Deltares is used to build a numerical model in order to simulate the tides in the North Sea. This model provides the boundary conditions for the more detailed wave and current model of the southern Northfrisian Wadden Sea. The bathymetry of the North Sea tide model is based on the ETOPO1 database with a cell grid size of one arc minute (Amante $\&$ Eakins 2009). The boundary conditions for the North Sea tide model are taken from the global tide model HAMTIDE by the Institute of Oceanography of the University Hamburg. It has a global resolution of 7.5' and includes a total of nine tidal constituents (Taguchi et al. 2010).

Table 3 lists the amplitudes and phases of the eight tidal constituents which were used at the northwest and the northeast edge of the northern model boundary. The values along the whole northern boundary are interpolated from these values at the model edges.

\begin{tabular}{|c|c|c|c|c|c|c|c|c|c|}
\multicolumn{6}{|c|}{ Table 3. Input tidal constituents at the northern boundary as extracted from the HAMTIDE- } \\
\multicolumn{2}{|c|}{} & M2 & S2 & N2 & K2 & K1 & 01 & P1 & Q1 \\
\hline \multirow{2}{*}{$\begin{array}{c}\text { North } \\
\text { west }\end{array}$} & Amplitude [m] & 0.5 & 0.18 & 0.1 & 0.0464 & 0.0837 & 0.0708 & 0.0249 & 0.0266 \\
& Phase [deg] & 270.53 & 299.78 & 250.9 & 302.7 & 171.3 & 27.62 & 160.44 & 340.56 \\
\hline $\begin{array}{c}\text { North } \\
\text { east }\end{array}$ & Amplitude [m] & 0.33 & 0.1 & 0.06 & 0.03 & 0.03 & 0.03 & 0.01 & 0.01 \\
Phase [deg] & 276.02 & 305.27 & 254.26 & 314.95 & 158.72 & 18.81 & 189.65 & 325.9 \\
\hline
\end{tabular}

Figure 7 displays the modelled water level in the North Sea at the time of tidal high water in the area of the Northfrisian Wadden Sea.

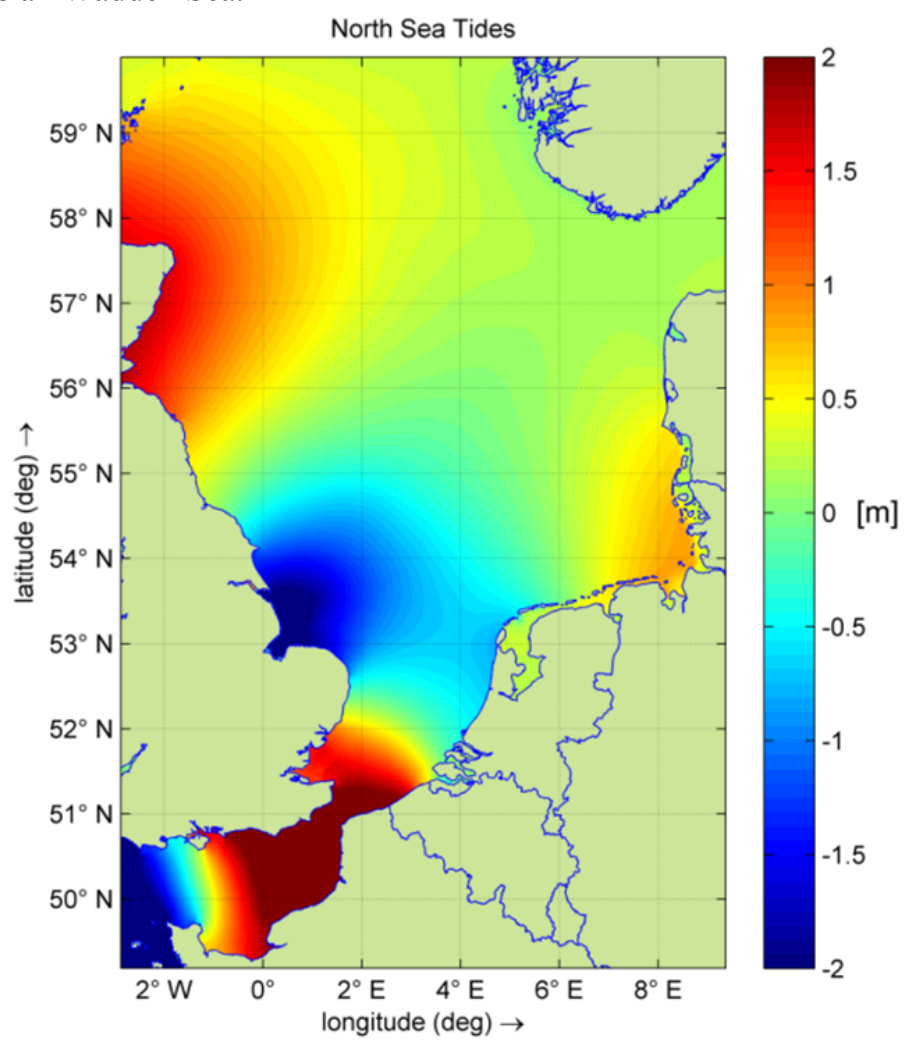

Figure 7. Modelled water levels in the North Sea at the time of high tide in the area of investigation 


\section{Detailed Model}

The more detailed model of the southern Northfrisian Wadden Sea is forced by boundary conditions which are generated by the large scale North Sea tide model. The cell size of the computational grid is $150 \mathrm{~m}$. The hydrodynamic conditions (water levels and currents) are simulated within the Delft3D-FLOW module and used as input data for the Delft3D-Wave module. Delft3DWave uses the SWAN wave model (Simulting Waves Nearshore) in the version 40.72A and is coupled to the Deflt3D-Flow module (Deltares 2010). The wave model was calibrated with the wave buoy data from the LKN-SH. After the calibration all wave simulations are performed in second-generation mode of SWAN as the simulated wave periods are overestimated in third-generation mode for the areas in the back of the islands. For the wave physics the default settings were used.

Figure 8 shows the development of the significant wave height under tidal influence and storm conditions with wind from $290^{\circ}$ and a wind speed of $24 \mathrm{~m} / \mathrm{s}$. The tidal inlets that flood and drain the tidal flats are permanently filled with water. In these tidal inlets, the greatest current velocities of about $2.5 \mathrm{~m} / \mathrm{s}$ occur. The dependence of the wave heights from the bathymetry of the Wadden Sea is as obvious as the protective effect of the high shoals which are located in the west of the Halligen. Furthermore the dependence of the wave height from the water level is obvious. With rising water levels the significant wave height increases. In the area of the tidal inlets the significant wave height is greater due to the greater water depth.
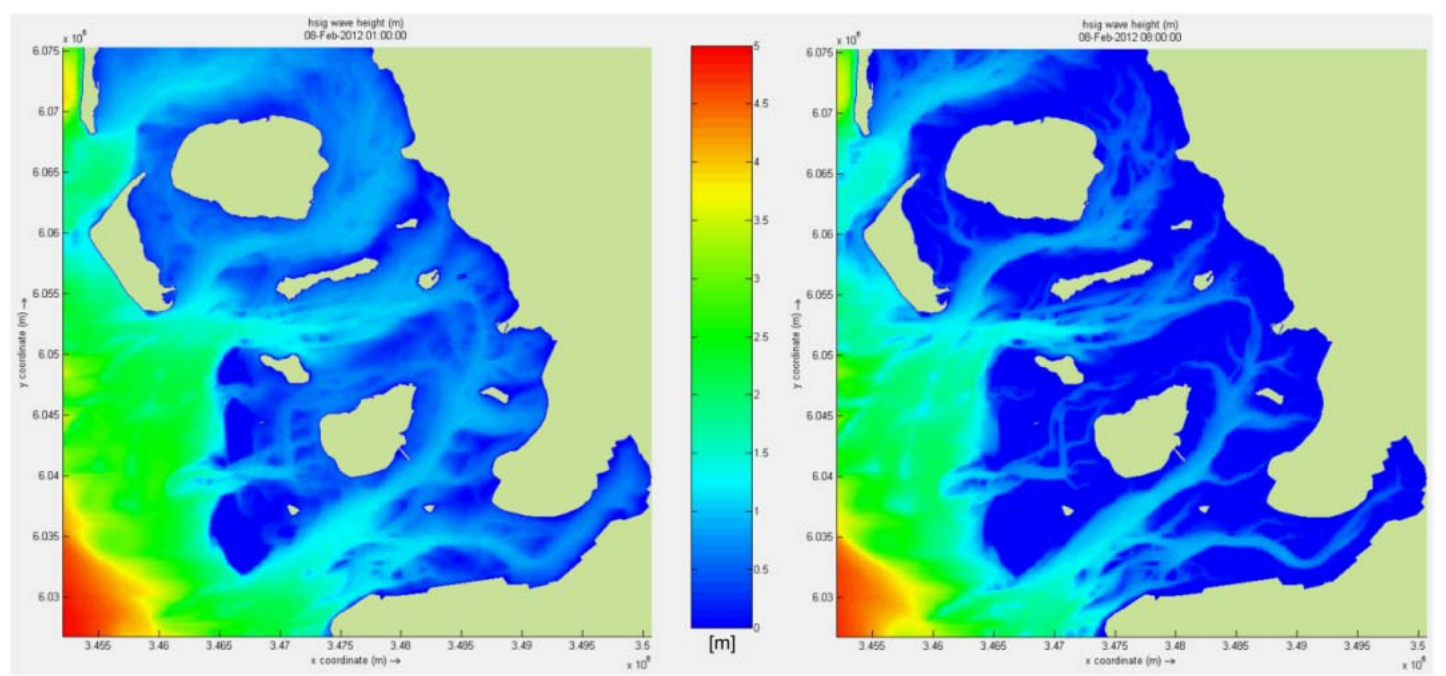

Figure 8. Significant wave height at high tide (left) and low tide (right) during storm conditions with wind from $290^{\circ}$ and a wind speed of $24 \mathrm{~m} / \mathrm{s}$

This high resoluted wave and current model for the whole area of investigation is again used to generate boundary conditions for computational grids with a cell size of $20 \mathrm{~m}$ for every Hallig. With the results of these computations the wave parameters at the toe of the dwelling mound are determined in order to calculate the wave overtopping for different scenarios.

\section{Inundation Simulation}

In the framework of the risk based hazard analyses inundation simulations with the decision support system ProMaIDes (Protection Measure against Inundation Decision Support) are performed. ProMaIDes was developed at the Institute of Hydraulic Engineering and Water Resources Management of the RWTH Aachen University. It allows

- hydrodynamic analyses,

- reliability analyses

- $\quad$ and analyses of the consequences.

The user is able to trigger storm surge hydrographs for past and future scenarios. The inundation simulation builds the basis of the analysis of the consequences (Bachmann 2012). 


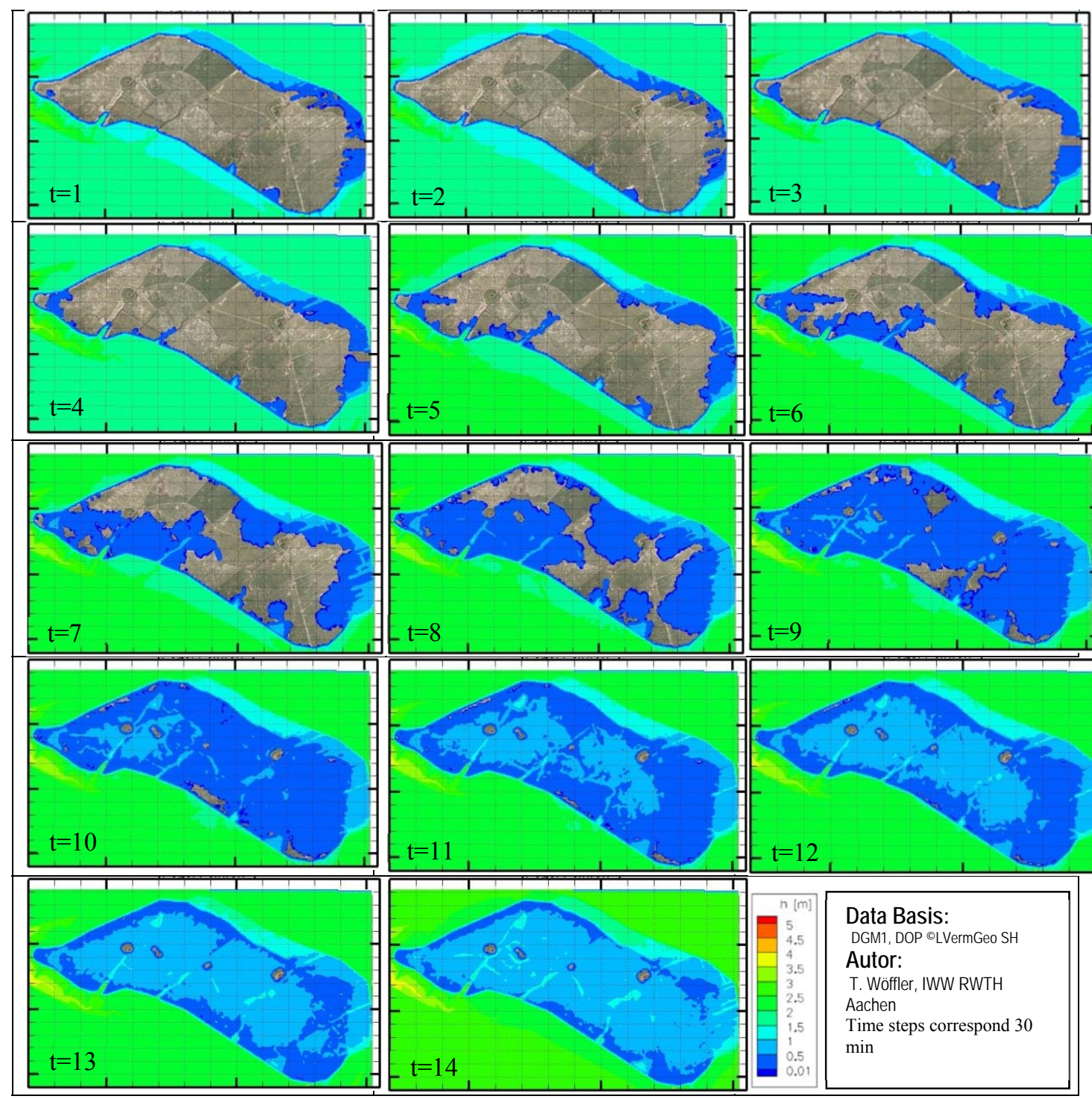

Figure 9. Inundation simulation of the Hallig Nordstrandischmoor based on the storm surge hydrograph of the gauge Büsum

Figure 9 demonstrates the inundation of the Hallig Nordstrandischmoor based on the storm surge hydrograph of the very high storm surge Capella from January 1976. With the rising water level the whole island gets inundated and only the four dwelling mounds remain dry. The houses on the dwelling mounds are eventually reached by water due to wave overtopping.

\section{Sensitivity Analysis}

With the help of the numerical flow and wave models, sensitivity analyses are performed to evaluate the hydrodynamic effectiveness of existing and possible new coastal protection measures and combinations. Theses sensitivity analyses reveal the hydrodynamic effects of new coastal structures and changes in the existing coastal structures (Niemeyer and Kaiser 2001). The changes in the existing coastal structures include measurements like an increase of the summer dikes, changes in the revetment profile or changes in the profile of the dwelling mound as well as artificial roughness elements. The evaluated coastal protection strategies are based on the three basic strategies

- Protection,

- Retreat and

- Accomodation. 
These three basic strategies defined by IPCC CZMS (1990) and the implied measures as well as combinations are evaluated in terms of hydrodynamic effectiveness.

The development of the significant wave height and wave period is investigated along cross sections in order to reduce wave energy and wave overtopping on the dwelling mound.

In Figure 10 the development of the significant wave height along two profiles in relation to different water levels under storm conditions is shown. The wave height decreases clearly at the edge of the Hallig and reaches values of about $1.4 \mathrm{~m}$ on the inundated Hallig for the highest water level. Higher water levels result in higher significant wave heights.

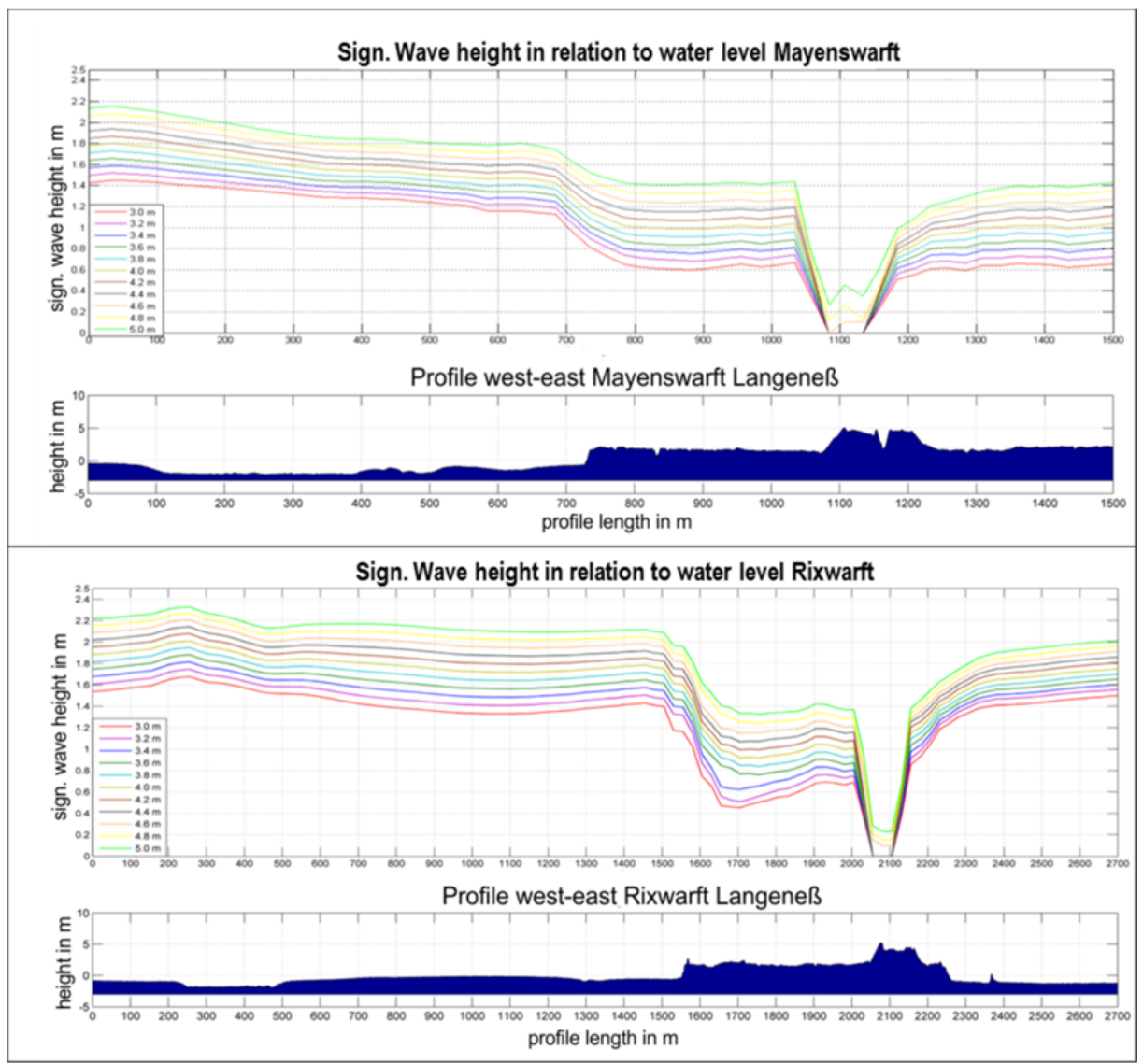

Figure 10. Significant wave heights in relation to different water levels along two profiles on the west coast of Hallig Langeneß

In the lower part of Figure 10 the hydrodynamic effectiveness of the summer dike is obvious as a sudden reduction in significant wave heights is taking place.

\section{CONCLUSIONS AND OUTLOOK}

With the tools and numerical models that were built up within the project ZukunftHallig it is now possible to analyse the hydrodynamic effectiveness of different coastal protection measures and their combinations for future storm surge scenarios. One of the main objectives within the project Zukunft Hallig is to reduce wave overtopping and wave energy on the dwelling mound. So various coastal protection strategies will be compared and evaluated with the shown tools.

Figure 11 categorizes possible coastal protection measures along a cross section on Hallig Hooge. A Hallig can be separated in three spatial zones for coastal protection measures.

At first there are the structural measures foreshore in zone A. These measures include groins, breakwaters, nourishments, gabions reclamation ditches, sedimentation fences or embankments.

The structural measures on the Hallig in zone B include elevated embankments, summer dikes, flood protection walls or bulkheads.

In zone $\mathrm{C}$, the dwelling mound, there is the possibility to build up a ring dike, flood protection walls or artificial roughness elements on the dwelling mound. Furthermore there is the possibility to do object protection or maybe floating houses are the solution for these small islands. Hydrodynamic 
effectiveness of these combined techniques and new measures are analysed by the described numerical simulations within the project.

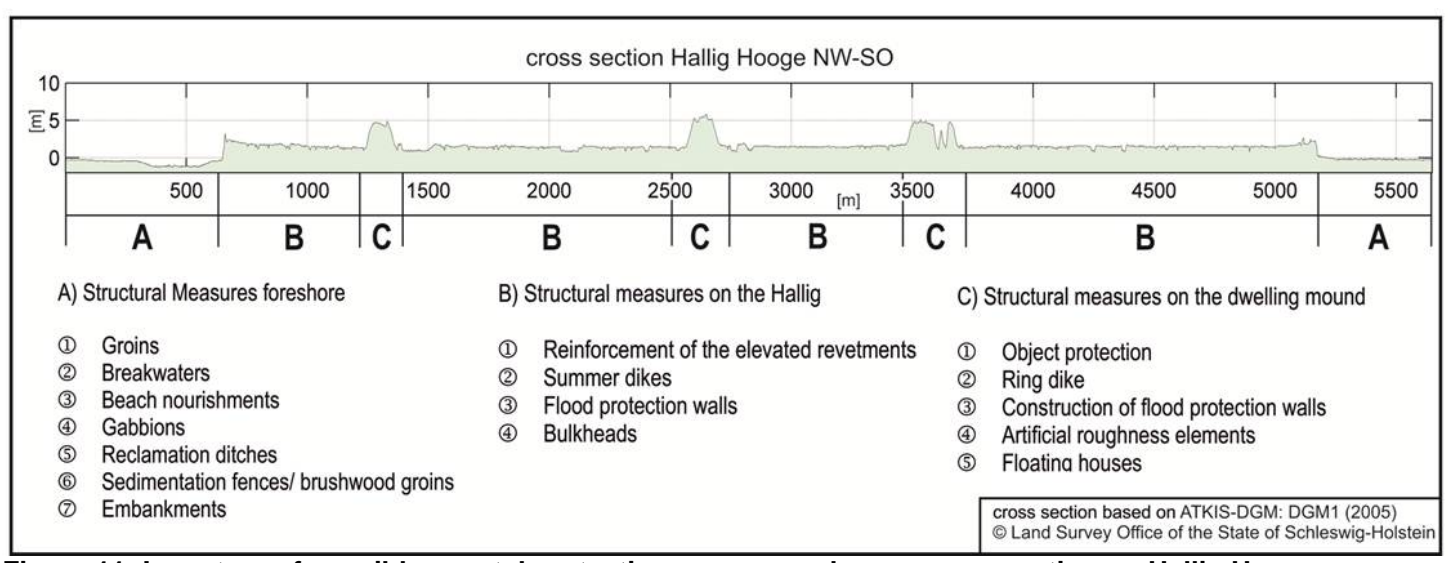

Figure 11: Inventory of possible coastal protection measures along a cross section on Hallig Hooge

\section{ACKNOWLEDGEMENTS}

The presented work is part of the KFKI (German Coastal Engineering Research Council) project ZukunftHallig and is founded by the German Federal Ministry of Education and Research (BMBF) (Project No. 03KIS094).

\section{REFERENCES}

Amante, C., and B. W. Eakins. 2009. ETOPO1 1 Arc-Minute Global Relief Model: Procedures, Data Sources and Analysis, National Geophysical Data Center, Marine Geology and Geophysics Division, Boulder Colorado, USA.

http://www.ngdc.noaa.gov/mgg/global/relief/ETOPO1/docs/ETOPO1.pdf, [Last access: 06.04.2012].

Arns, A., D. Blutner, H. von Eynatten, R. Häußling, F. Jensen, V. Karius, C. Mudersbach, D. van Riesen, M. Schindler, H. Schüttrumpf, H. Strack, T. Wöffler, and J. Jensen. 2012. Developing sustainable coastal protection- and management strategies for Schleswig-Holstein's Halligen considering climate changes (ZukunftHallig), Proceedings of the $5^{\text {th }}$ International Short Conference on Applied Coastal Research, Aachen.

Bachmann, D. 2012. Beitrag zur Entwicklung eines Entscheidungsunterstützungssystems zur Bewertung und Planung von Hochwasserschutzmaßnahmen, Dissertation, Aachen, Institut für Wasserbau und Wasserwirtschaft, RWTH Aachen. http://darwin.bth.rwth-aachen.de/opus3/volltexte/2012/4043/, [Last access: 30.07.2012].

Deltares. 2010. Delft3D-Wave, Simulation of short-crested waves with SWAN, User Manual, Version 3.04 .

Ehlers, J. 1988. The morphodynamics of the Wadden Sea, A. A. Alkema, Rotterdam.

Eurotop. 2007. Eurotop - Wave Overtopping of Sea Defences and Ralted Structures: Assessment Manual, In: Die Küste : Archiv für Forschung und Technik an der Nord- und Ostsee, Archive for research and technology on the North Sea and Baltic Coast / Hrsg. Kuratorium für Forschung im Küsteningenieurwesen, Boyens, Heide in Holstein.

IPCC CZMS. 1990. Strategies for Adaption to Sea Level Rise, Report of the Coastal Zone Management Subgroup, Response Strategies Working Group of the Intergovernmental Panel on Climate Change, Ministry of Transport, Public Works and Water Management, The Hague, Netherlands.

Merz, B. 2006. Hochwasserrisiken - Grenzen und Möglichkeiten der Risikoabschätzung, Schweizerbart'sche Verlagsbuchhandlung, Stuttgart.

Niemeyer,H. D. and R. Kaiser. 2001. Hydrodynamische Wirksamkeit von Lahnungen, Hellern und Sommerdeichen, In: Die Küste: Archiv für Forschung und Technik an der Nord- und Ostsee, Archive for research and technology on the North Sea and Baltic Coast / Hrsg. Kuratorium für Forschung im Küsteningenieurwesen, Boyens, Heide in Holstein. 
Pachauri, R. K., and A. Reisinger. 2007. Contribution of Working Groups I, II and III to the Fourth Assessment Report of the Intergovernmental Panel on Climate Change, IPCC, Geneva, Switzerland.

Taguchi, E., D. Stammer, and W. Zahel. 2010. Estimation of deep ocean tidal energy dissipation based on the high-resolution data-assimilative HAMTIDE-model (to be submitted to J. Geophys. Res.). http://icdc.zmaw.de/hamtide.html?\&L=1, [Last access: 04.12.2011]. 